\title{
LEGAL AND ORGANIZATIONAL FRAMEWORK FOR THE USE OF GEOWEB METHODS FOR PUBLIC PARTICIPATION IN SPATIAL PLANNING IN POLAND: EXPERIENCES, OPINIONS AND CHALLENGES
}

\author{
Edyta BąKowska-Waldmann ${ }^{1}$, Cezary BrudKa², Piotr Jankowski ${ }^{3,4}$ \\ ${ }^{1}$ Institute of Socio-Economic Geography and Spatial Management, \\ Adam Mickiewicz University in Poznań, Poland \\ ${ }^{2}$ Poznań University of Economics, Poznań, Poland \\ ${ }^{3}$ Department of Geography, San Diego State University, USA \\ ${ }^{4}$ Institute of Geoecology and Geoinformation, Adam Mickiewicz University in Poznań, Poland
}

Manuscript received: May 17, 2018

Revised version: July 9, 2018

\begin{abstract}
BĄKOWSKA-WaLDMANn E., BRUDKA C., JANKOWSKI P., 2018. Legal and organizational framework for the use of geoweb methods for public participation in spatial planning in Poland: experiences, opinions and challenges. Quaestiones Geographicae 37(3), Bogucki Wydawnictwo Naukowe, Poznań, pp. 163-175. 7 figs, 1 table.

ABSTRACT: Geoweb methods offer an alternative to commonly used public participation methods in spatial planning. This paper discusses two such geoweb methods - geo-questionnaire and geo-discussion in the context of their initial applications within the spatial planning processes in Poland. The paper presents legal and organizational framework for the implementation of methods, provides their development details, and assesses insights gained from their deployment in the context of spatial planning in Poland. The analysed case studies encompass different spatial scales ranging from major cities in Poland (Poznań and Łódź) to suburban municipalities (Rokietnica and Swarzędz in Poznań Agglomeration). The studies have been substantiated by interviews with urban planners and local authorities on the use and value of Geoweb methods in public consultations.
\end{abstract}

KEY WORDS: spatial planning, Geoweb, geo-questionnaire, geo-discussion, public consultations

Corresponding author: Edyta Bąowska-Waldmann, edyta.bakowska@amu.edu.pl

\section{Introduction}

The idea of public participation in urban planning is based on the concept that space is shaped by inhabitants of a given area, who make specific ties with it, identify with it and relate to it. Residents are also one of the most important groups affected by changes in spatial development and should be included in the process of decision making in light of contemporary governance models in participatory democracy (Herbst 2014, Siemiński 2014). Conflicts between different stakeholders related to space and land-use are an inherent aspect of urban planning. The syndromes such as NIMBY (Not In My Back Yard), in which there is a conflict between the common good and the good of the local community during the investment process are typical in spatial planning and well described in the literature (Kraft \& Clary 1991, Dear 1992, 
Matczak 1996). According to the report prepared by the Foundation for the Development of Local Democracy and Institute of Geography and Spatial Development of the Polish Academy of Science (2013) urban planning including broader group of stakeholders, equipped with instruments of public participation, limits possible conflicts in the process of urban planning.

Public participation is characterized by the use of a variety of formal and informal tools that enable members of a given community to express their values, expectations and preferences to the authorities (Banyan 2007, Brabham 2009). It is a manifestation of changes towards the public governance, represented in legal and organizational improvements in administration and management (Herbst 2014). In the Web 2.0 era, improvements in information technologies triggered development of the tools related to the Internet map services (Geoweb) available for lay people (Haklay et al. 2008, Gryl et al. 2010, Henning et al. 2013, Brown, Kytta 2014, Johnson et al. 2015). The emergence of these new tools can change the ways of interactions between public administration and inhabitants, improving the accessibility to decision-making processes (Anttiroiko 2012, Kahila-Tani et al. 2016).

The goal of the paper is to present legal and organizational framework for the implementation of two specific Geoweb methods - geo-questionnaire and geo-discussion developed by Jankowski et al. $(2016,2017,2018)$ - in spatial planning in Poland, as well as opinions of urban planners and local authorities on the use of tools in public consultations. The applicability of Geoweb methods for the planning procedures in the city of Łódź and in Poznan agglomeration, Poland is examined on the bases of six case studies including four implementations of geo-questionnaire and two of geo-discussion. The examination is guided by the following research questions:

1. How formal and legal aspects determine the use of Geoweb methods in urban planning in Poland within a formal planning procedure?

2. How urban planners and local authorities can benefit from the use of Geoweb methods in public consultations in spatial planning?

3. At what respective stages of the planning procedure can geo-questionnaire and geo-discussion methods can be used in support of public consultation process in spatial planning in Poland?

\section{Methods}

The methods used in the analysis of case studies involving the applications of geo-questionnaire and geo-discussion (Jankowski et al. 2016, 2017, 2018) included: (1) qualitative analysis of case studies, (2) interviews with urban planners and local authorities, and (3) legal acts analysis.

\section{Case studies analysis}

Case studies analysis was conducted in connection with pilot implementations of geo-questionnaire and geo-discussion in the City of Łódź and Poznań Agglomeration (Poznań, Swarzędz and Rokietnica). The case study method has been chosen as a method of empirically investigating current processes of public participation in spatial planning in Poland. This investigation has been framed by considering the influence of legal and organizational aspects that can either permit or

Table 1. Characteristics of the case studies analyzed in the paper.

\begin{tabular}{|l|l|l|l|l|}
\hline \multicolumn{1}{|c|}{ Name } & \multicolumn{1}{|c|}{ Localization } \\
$\begin{array}{l}\text { New Center of } \\
\text { Rokietnica }\end{array}$ & $\begin{array}{l}\text { Rokietnica (Poznań } \\
\text { agglomeration) }\end{array}$ & $\begin{array}{l}\text { Geoweb method } \\
\text { geo-discustionnaire } \\
\text { geo-discussion }\end{array}$ & $\begin{array}{l}\text { Rokietnica Municipal } \\
\text { Office, } \\
\text { Urban Planning Office } \\
\text { (private company) }\end{array}$ & $\begin{array}{l}\text { Development of the } \\
\text { brown-field in the village } \\
\text { center }\end{array}$ \\
\hline $\begin{array}{l}\text { Kobylnica sports } \\
\text { Airport }\end{array}$ & $\begin{array}{l}\text { Swarzędz (Poznań } \\
\text { agglomeration) }\end{array}$ & geo-questionnaire & $\begin{array}{l}\text { Swarzędz Municipal } \\
\text { Office }\end{array}$ & $\begin{array}{l}\text { New land-use plan for the } \\
\text { former sports airfield }\end{array}$ \\
\hline Andrzejów & Eódź & geo-questionnaire & $\begin{array}{l}\text { Urban Planning Office } \\
\text { of Łódź }\end{array}$ & $\begin{array}{l}\text { Regulate previously } \\
\text { unregulated urbanization of } \\
\text { eastern outskirts of the city }\end{array}$ \\
\hline Kasprowicz Park & Poznań & $\begin{array}{l}\text { geo-questionnaire } \\
\text { geo-discussion }\end{array}$ & $\begin{array}{l}\text { Urban Planning Office } \\
\text { of Poznań }\end{array}$ & $\begin{array}{l}\text { Regulate the land use of a } \\
\text { recreational area in the city } \\
\text { (including allotment gardens) }\end{array}$ \\
\hline
\end{tabular}


detract from the use of Geoweb methods (Robson 1993, Yin 2003). The aim of the conducted case studies was to understand and explain the potential and actual benefits of geo-questionnaire and geo-discussion use in the planning processes. Such research design represents the explanatory type of case study according to Yin (2003). The examples examined in the paper refer to the planning processes related to the procedure of local spatial development plans preparation resulting from the legal act on Spatial Planning and Management (2003). Table 1 presents the characteristics of case studies.

The listed above case studies had been carried out during the period of three years between 2014 and 2017 and involved four implementations of geo-questionnaire and two of geo-discussion. All of the cases represented a top-down approach to public consultations, in which local authorities and urban planners are directly responsible for the preparation of local spatial development plans and where it is up to them to initiate/organize public participation in the planning process (Talen 2000, Sieber 2006).

\section{Interviews}

The total number of 16 interviews were conducted in the second half of 2015 as part of the selection of pilot implementations of geo-questionnaire and geo-discussion within the project 'Geoportal supporting public participation in spatial planning' funded by the grant from the National Center for Research and Development within the Applied Research Programme. The interviews were conducted prior to implementing the methods. The respondents represented local authorities (2), representatives of local planning agencies $(3$, urban planners and other specialists responsible for spatial planning with different educational background) and employees from other departments at City/Municipal Hall (11). The interview questions addressed the agencies' interest in and openness towards the use of geo-questionnaire and geo-discussion. Respondents were asked the same questions (semi-structured interview), during the 1-hour long meetings. Respondents were asked for:

- what features (functions) should a public consultation tool have in order to meet their expectations and be useful in their work,
- limitations in the currently used public consultation methods that could be lifted by the Geoweb methods,

- needs for using Geoweb methods in their work.

\section{Document analysis}

Spatial planning and public involvement in spatial planning processes in Poland are regulated by law. In order to present the legal determinants for the possibility of using Geoweb methods in spatial planning, the document of Spatial Planning and Management act of 2003 was analyzed with focus on regulations pertinent to public participation. To correctly interpret the provisions of the mentioned legal acts, the interpretations of the act as well as judicial decisions concerning planning processes in Poland were also investigated.

\section{Spatial planning in Poland}

The foundations of the spatial planning process in Poland were laid down by the Regulation of the President of the Republic of Poland from 1928, which indicated the need for caring about public interest and for basic forms of public involvement in the process of spatial planning. After the World War II there was a definite centralization of the spatial planning in Poland, and the interest of the state was put before the interest of citizens and property owners. Another law on spatial planning from 1984 introduced mechanisms for socialization of spatial planning process. However, due to the need to respect government guidelines, citizens' voice did not matter. The change in the socio-political and economic system of the Republic of Poland in 1990 influenced the decentralization of the spatial planning system and the creation of local self-governments - communes (gminy), having a certain level of autonomy in the decision-making at a local level (Niewiadomski 2002). As part of the reforms undertaken at the beginning of the 1990s, a new land use law was adopted in 1994 with the aim to align the legislation to the existing state system, as well as to European standards and in view of aspirations for membership in European Union and other world organizations. The 1994 
law paid special attention to the protection of the legal interests of property owners, giving them the possibility to pursue claims in cases of their violation. Giving to local self-governments the exclusive right of decision in spatial planning the law emphasized their role as landowners and the basic element of the spatial planning system in Poland (Niewiadomski 2002, Parysek 2007).

\section{Process of spatial planning in Poland}

Geoweb methods facilitating public involvement in spatial planning are an example of non-statutory methods that can increase participation in planning processes in Poland. By getting involved in the pilot implementations the authors were looking for opportunities to integrate these non-statutory methods of public consultations with the statutory procedure of developing local spatial development plan.

The process of spatial planning in Poland is defined by the Act of 27 March 2003 on Spatial Planning and Management that distinguishes three hierarchical levels of spatial planning in Poland. The planning levels correspond to government levels in Poland excluding the subregional level of county, which has limited spatial planning competencies. The three levels of spatial planning in Poland include: local, regional and national (Fig. 1). Despite the importance of all three levels the authors focused on the local (municipal) level, at which the use of geo-questionnaire method has been examined.

At the time of this writing, the geo-questionnaire method has been applied only at a local level in the preparation of local spatial development plan - the local legal act whose stipulations are derived from a statutory document called "a

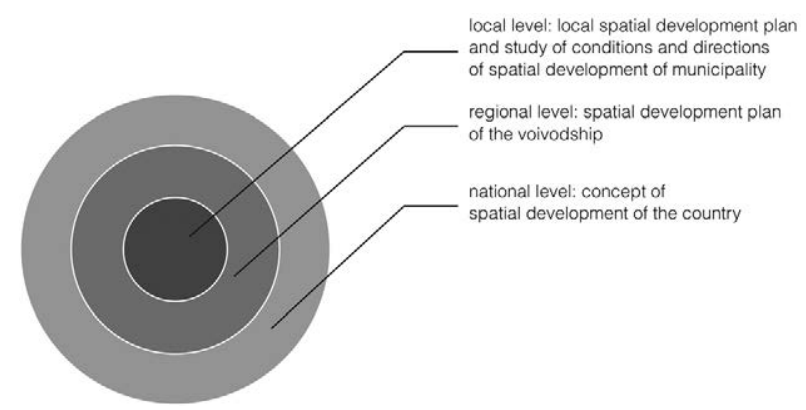

Fig. 1. Levels of spatial planning in Poland (based on the Act of 27 March 2003 on Spatial Planning and Management). study of conditions and directions of spatial development", usually prepared by a local planning agency in consultation with various stakeholders. The competences of municipalities in terms of spatial planning are defined as the planning authority (wladztwo planistyczne in Polish), which means the exclusive right of decision on spatial development of the municipality (Niewiadomski 2002, Parysek 2007).

The planning procedure at the local level has been defined in detail in the Act on Planning and Spatial Management, both for local spatial development plans and for the studies of conditions and directions of spatial development for municipalities. Figure 2 presents the procedure for the preparation of local spatial development plan, which is similar to the procedure used during the preparation of spatial development study for municipality.

The constitution of the Republic of Poland (Act of 2 April 1997) provides legal bases for
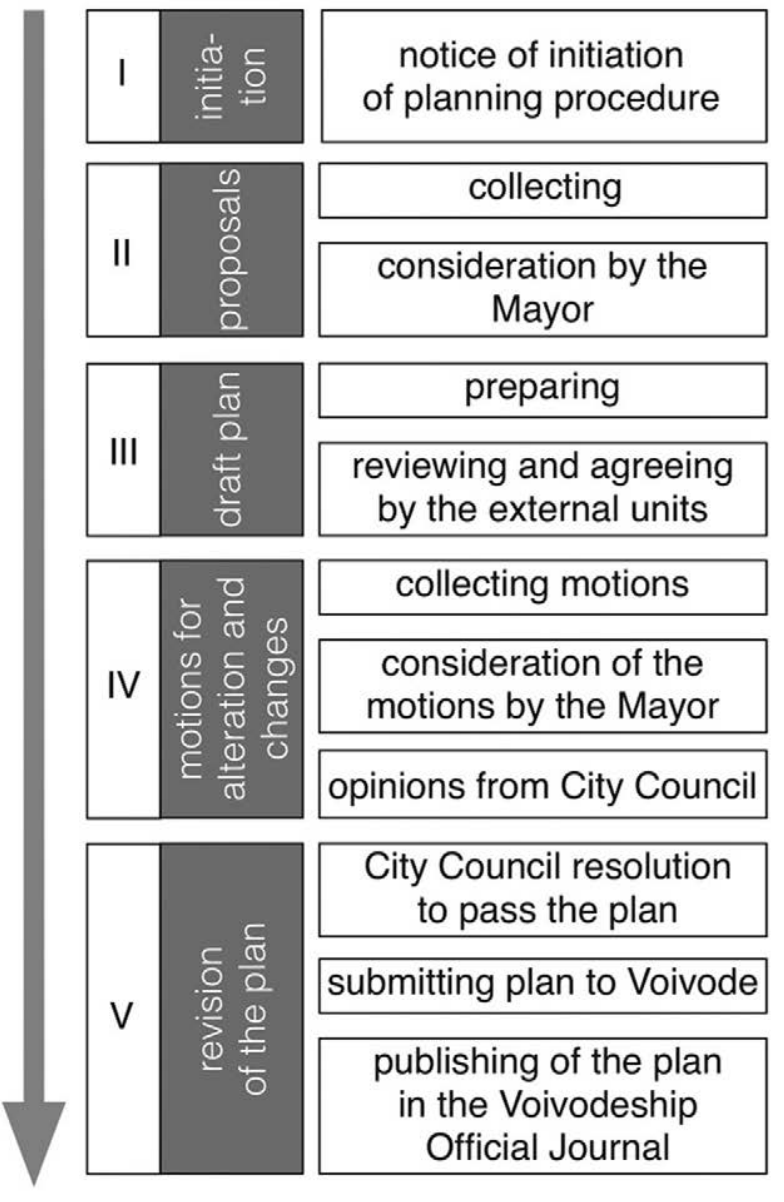

City Council resolution to pass the plan

\begin{tabular}{|c|}
\hline submitting plan to Voivode \\
\hline $\begin{array}{c}\text { publishing of the plan } \\
\text { in the Voivodeship } \\
\text { Official Journal }\end{array}$ \\
\hline
\end{tabular}

Fig. 2. Local spatial development plan preparation procedure (based on the Act of 27 March 2003 on Spatial Planning and Management). 
functioning of local governments and their competences detailed in the Local Government Act of 1990, indicating spatial planning as the municipality's own task. The spatial planning should be in line with separate legal regulations concerning the protection of environment, protection of agricultural and forest lands, protection of monuments, management of water, construction processes, special purpose investments (roads, harbours, airports, etc.) as well as future property management (Radeberg-Skorzysko 2016).

\section{Legal bases for public involvement in the process of urban planning}

Commonly, in democratic societies public participation in planning and local decision making is legally regulated (Siemiński 2014). This includes the right to vote, organize referenda, and to create citizen advisory bodies. According to one of the first Polish definitions

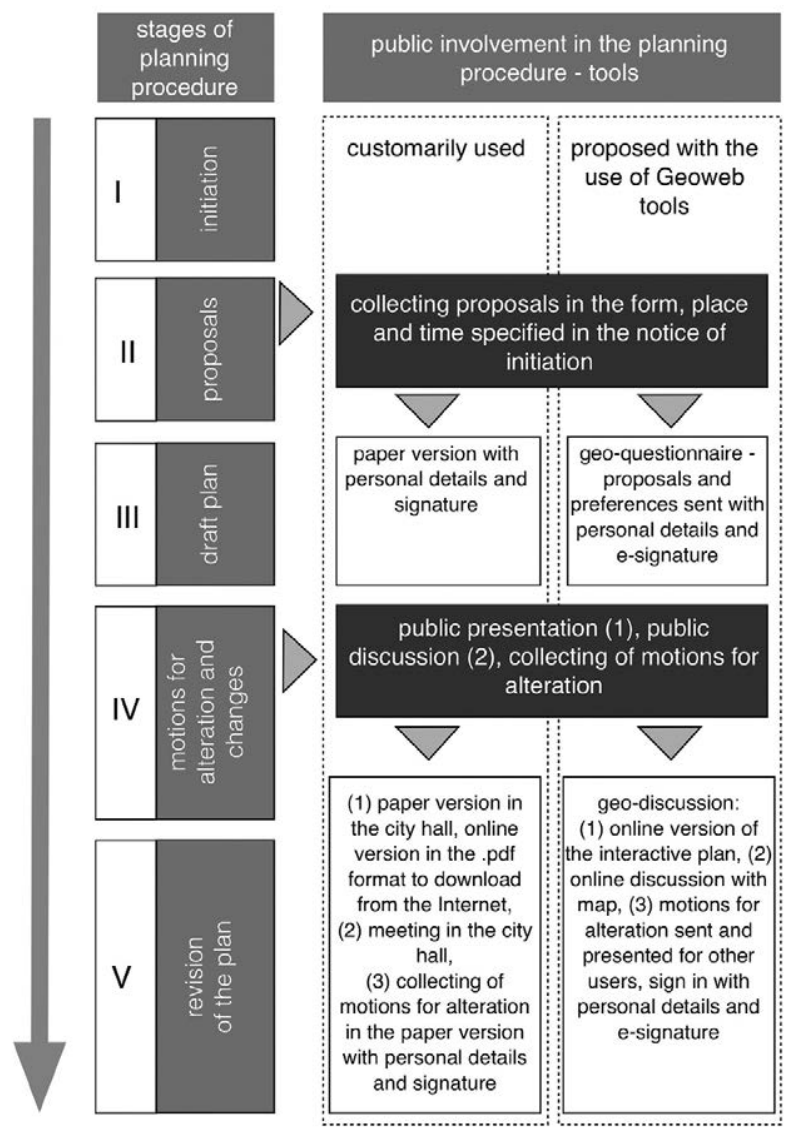

Fig. 3. Public involvement in spatial planning in Poland (based on the Act of 27 March 2003 on Spatial Planning and Management). of public participation in spatial planning given by Wiench (acc. to Siemiński 2014), it is a legal action of individuals and social groups in order to influence the determination of spatial development plan. Public participation in Poland is a relatively young phenomenon, mostly present in the process of urban planning and regulated by the Act of 27 March 2003 on Spatial Planning and Management.

The primary avenue for public participation in spatial planning, in its statutory form resulting from the Act of 27 March 2003, is the possibility to submit proposals and comments to local spatial development plan and the study of spatial planning conditions and directions at a certain time of the planning procedure (Fig. 3).

Despite the statutory possibility of the participation of all interested parties in the planning procedure, according to the law, private land owner interests trump public interests, which in effect may render any input from the participating public irrelevant at the stage of decision making (Zachariasz 2014). However, the legal basis determining the form of public participation in public consultation accompanying spatial planning does not limit the possibility of using additional non-statutory methods, often regulated by a local law, obligating local authorities to apply them in matters related to public interest.

\section{Possibilities for including Geoweb methods in spatial planning in Poland}

The use of GIS (Geographical Information Systems) is relatively common in Polish planning offices, especially in larger cities. However, GIS is used mainly for the purpose for storing geographical data and supporting the actual (i.e., rational) planning where the use of GIS for communication with external stakeholders has been so far limited. Figure 3 presents the stages of planning procedure, in which the Geoweb tools could be used. They correspond to the stages, in which the legislator indicated the possibility of public participation. In the first stage of involving the public, proposals in the form of comments and annotations on the plan draft may be sent via a communication tool (e.g., geo-questionnaire) provided by the agency responsible for the preparation of plan draft. In the second stage - the public 
presentation of the plan, public involvement can be enabled by the geo-discussion tool, which enables the presentation of an interactive version of the plan with its detailed regulations. The same tool also allows discussion between the interested actors about plan regulations and comments of other participants. The possibility of commenting on proposed regulations refers to collecting motions for alteration of the draft plan. While it is technically possible to introduce Geoweb tools in the planning procedure in Poland, from the legal point of view, according to the Regulation of the Minister of Infrastructure from 26 August 2003 on the required scope of the local spatial development plan, the proposals and comments on the plan draft should be accompanied by signature (or electronic signature) and personal details of the person submitting them. This requirement represents the most important challenge for the adoption of Geoweb methods in Poland, which otherwise offer the scalability potential to involve more participants than traditional participation methods and new participants (e.g., young population groups) who tend to stay away (Jankowski et al. 2017). PPGIS tools (and Internet tools in general) have great potential of engaging younger citizens. According to Eurostat (2017), everyday use of Internet in 2016 was higher among young people (16-29) than for the whole population in each of the European Union Member Countries. According to the report since 2012 the use of Internet among young people is higher than the use of computer obviating the need for the development of mobile applications to encourage the involvement of this group in local issues. One of the early studies investigating the involvement of younger citizens from Finland and Sweden in spatial planning mediated by PPGIS have shown the potential but also possible constraints and challenges in use of mobile maps among younger citizens, especially children (Broberg et al. 2013, Nordin and Berglund 2010).

\section{Characteristics and uses of geo-questionnaire}

Geo-questionnaire is an online questionnaire augmented with functionality of an online map (Jankowski et al. 2016). Respondents can answer the questions, among the others, by drawing geographic objects (points, lines and polygons) on a basemap provided by the designer of the questionnaire (Fig. 4). The objects can represent, for example, locations of specific problems in space, suggestions of future developments or any other phenomenon located in the geographic space. The data obtained with the questionnaire is then

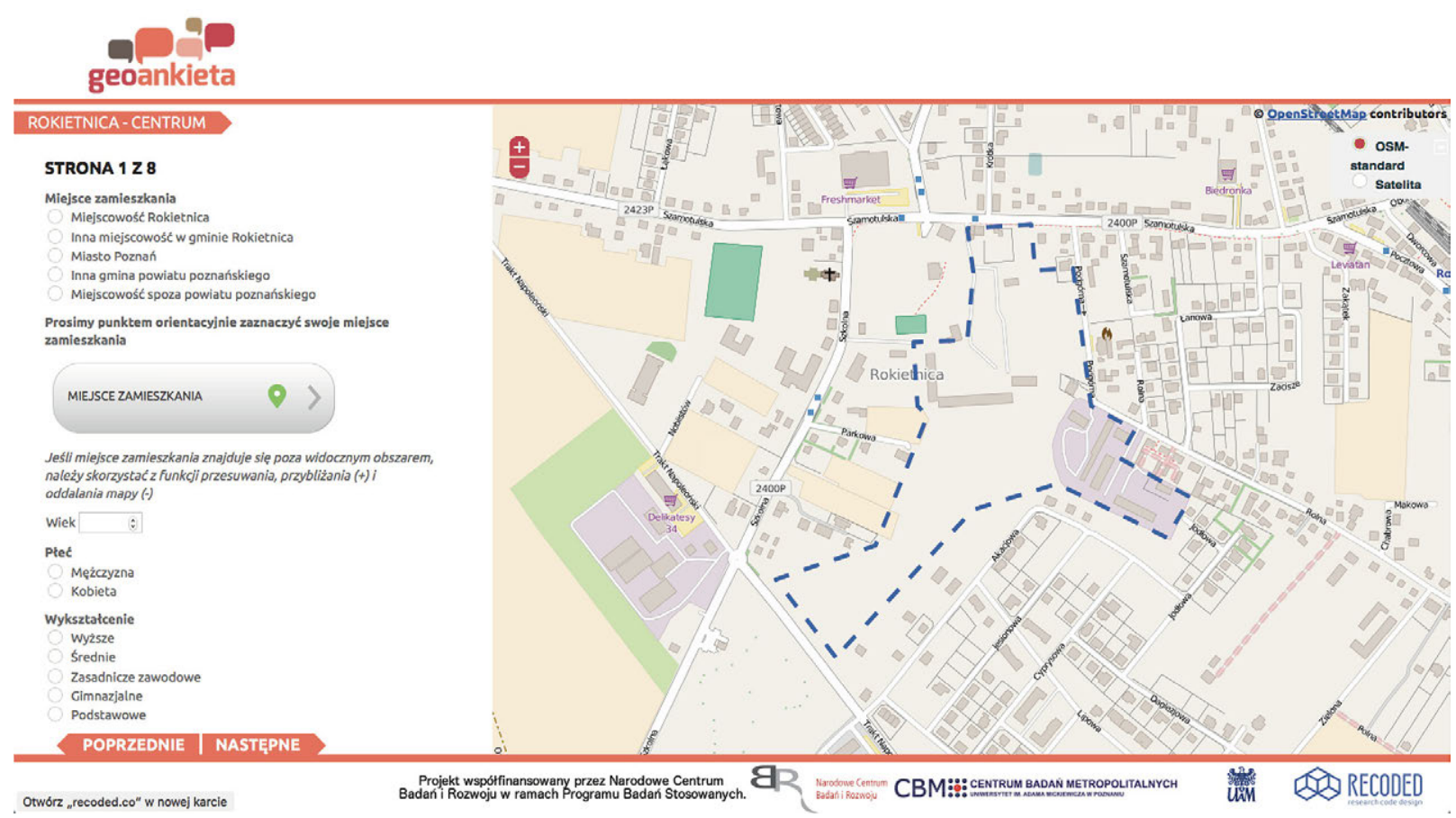

Fig. 4. Example of a geo-questionnaire used in the public consultations in Rokietnica. The page shows tools that can be used to answer the questions. 
processed by the software and stored in a GIS database, which allows further analysis.

Geo-questionnaire shares several characteristics with traditional (PAPI - Paper \& Pen Personal Interview) questionnaires. One of the most important is that it is unidirectional, which means that the flow of information is directed generally from the respondent to the recipient, who most commonly would also be the designer and organiser of the survey. The other characteristic is that of independence of answers from each other - each respondent is presented with the same questions throughout the survey and cannot see the answers of other respondents. This prevents the phenomenon of feedback loop that could lead to the so called snowball effect, under which initial answers could channel further discussion and therefore have excessive influence on the survey outcome.

The abovementioned characteristics determine the range of possible uses of geo-questionnaire in spatial planning. The most common uses involve those where data recipient (usually a sponsor or organizer of geo-questionnaire) wants either to obtain respondents' local knowledge or elicit their preferences towards the area in question. In a typical setting, both of those situations take place at the very beginning of the planning process, during the strategic diagnosis of the area or the early initiation of the planning, which correspond to phase I in Fig. 5. The geo-questionnaire can also be used to collect early proposals for the considered area, which roughly correspond to the phase of collecting motions to the plan in the statutory procedure.

One other important characteristic of geoquestionnaire is its potential to generate quantitative data. Since all respondents answer the same set of questions, the obtained data can be analysed with the use of quantitative methods, including the measures of spatial autocorrelation and cluster analysis. The digital form of the

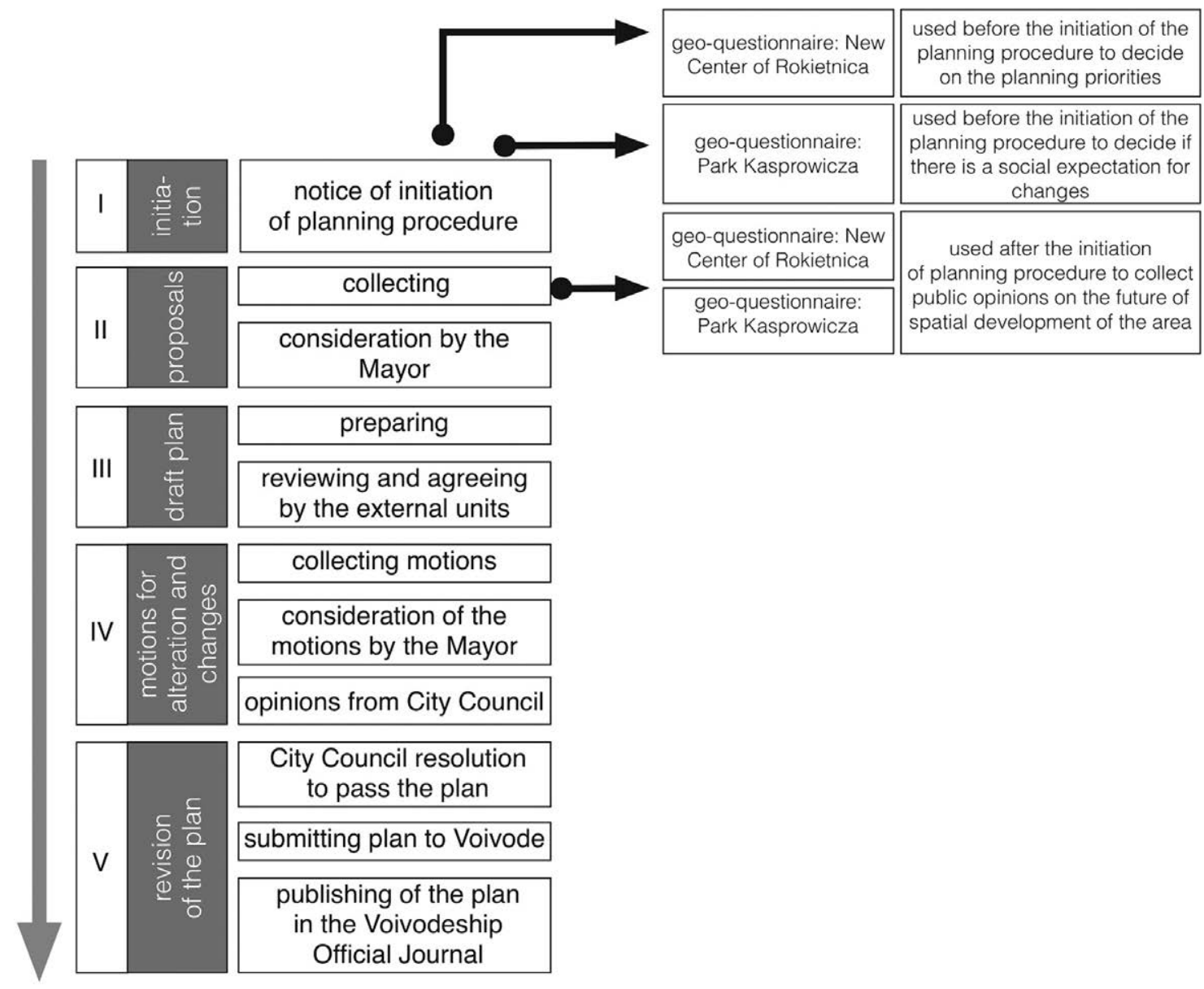

Fig. 5. Implementation of geo-questionnaire within the planning procedure of the analyzed local spatial development plans. 
questionnaire and automatic storage in an electronic database allows for the collection and analysis of relatively large numbers of questionnaires (compared to the time-consuming digitalisation of PAPI questionnaires).

It is important to note, that all of the mentioned uses share a common feature of unidirectional flow of relatively big volumes of structured information (knowledge of the current state of area under plan consideration, preferences, proposals) from respondents to the recipients. This characteristic differentiates qeo-questionnaire from geo-discussion.

In the analyzed case studies, geo-questionnaire was used at the stages of early initiation and collecting proposals (see Fig. 5). In each example, the implementation of geo-questionnaire was included in the processes of public consultations led by the researchers in cooperation with local governments. Local authorities and urban planners participated in the preparation and implementation phases. They were also the main recipients of data collected during public consultations.

In the case of Andrzejów (district of Łódź), the geo-questionnaire was designed before any formal decisions were made on the starting of planning procedure. After the official initiation of the planning process, the geo-questionnaire was used not only to carry out a diagnosis of the area in question, but also to help the planners decide about the priority of different parts of the plan. The use of geo-questionnaire resulted in the identification of guidelines for further planning activities in the subsequent stages of the planning procedure, most importantly during drafting of the local spatial development plan.

Similarly, in Kobylnica's example the tool was used to explore public expectations towards the change of land use directions for the local air-glider airfield. The aim of that implementation was to obtain the opinion of local inhabitants on the desired directions of redevelopment of the former sports airfield. The commune authorities adopted a position in the negotiations with current and future owners of that area on the basis of the diagnosis of inhabitants' opinion.

Two other uses of geo-questionnaire in spatial planning considered in this paper, i.e. Park Kasprowicza (Jankowski et al. 2016) and New Centre of Rokietnica, took place at the phase of collecting motions and proposals. This coincided with the collection of motions in statutory process, organized in the form of a public meeting, and can be seen as a way to extend the official statutory procedure with a Geoweb method.

\section{Characteristics and uses of geo-discussion}

Geo-discussion is an online forum for opinions augmented with functionality of an online map. The participants can familiarise themselves with the interactive material (see Fig. 6) provided by the organisers of the discussion (e.g. a project of a local land-use plan) and react to it publicly. The range of possible reactions contains among the others: expressing support or disapproval for a specific part of the project; commenting on the content; sharing the content in social media or replying to other participants' comments. According to a chosen set-up of geo-discussion, the participants can either relate to the pre-defined geographical objects (e.g. subdivisions of the designed plan) or digitize their own objects (points, lines or polygons) on the provided basemap. Similarly as with the case of geo-questionnaire, the data is then processed and stored in an online GIS database.

Geo-discussion shares some of its characteristics with online forums or social media; the participants have a broad range of tools available to allow mutual interactions that can facilitate exchanging information, finding commonalities and differences of opinion. The introduction of personal accounts and nicknames bears another similarity to the today's social media - this allows the tool to notify participants about a new activity in the discussion, which induces further exchange of opinions.

It is important to note that not only members of the public can participate in geo-discussion. Personal and active participation of the plan's designer(s) or the representatives of local authority can lead not only to acquiring new knowledge and collecting motions, but also to enhancing communication between the authorities and citizens. The features of geo-discussion allow citizens to actively assist in creation of spatial development plans and other projects connected with urban design. However, another, next to civic engagement, crucial matter is how local authorities will take advantage from the knowledge obtained from inhabitants during public consultations. 


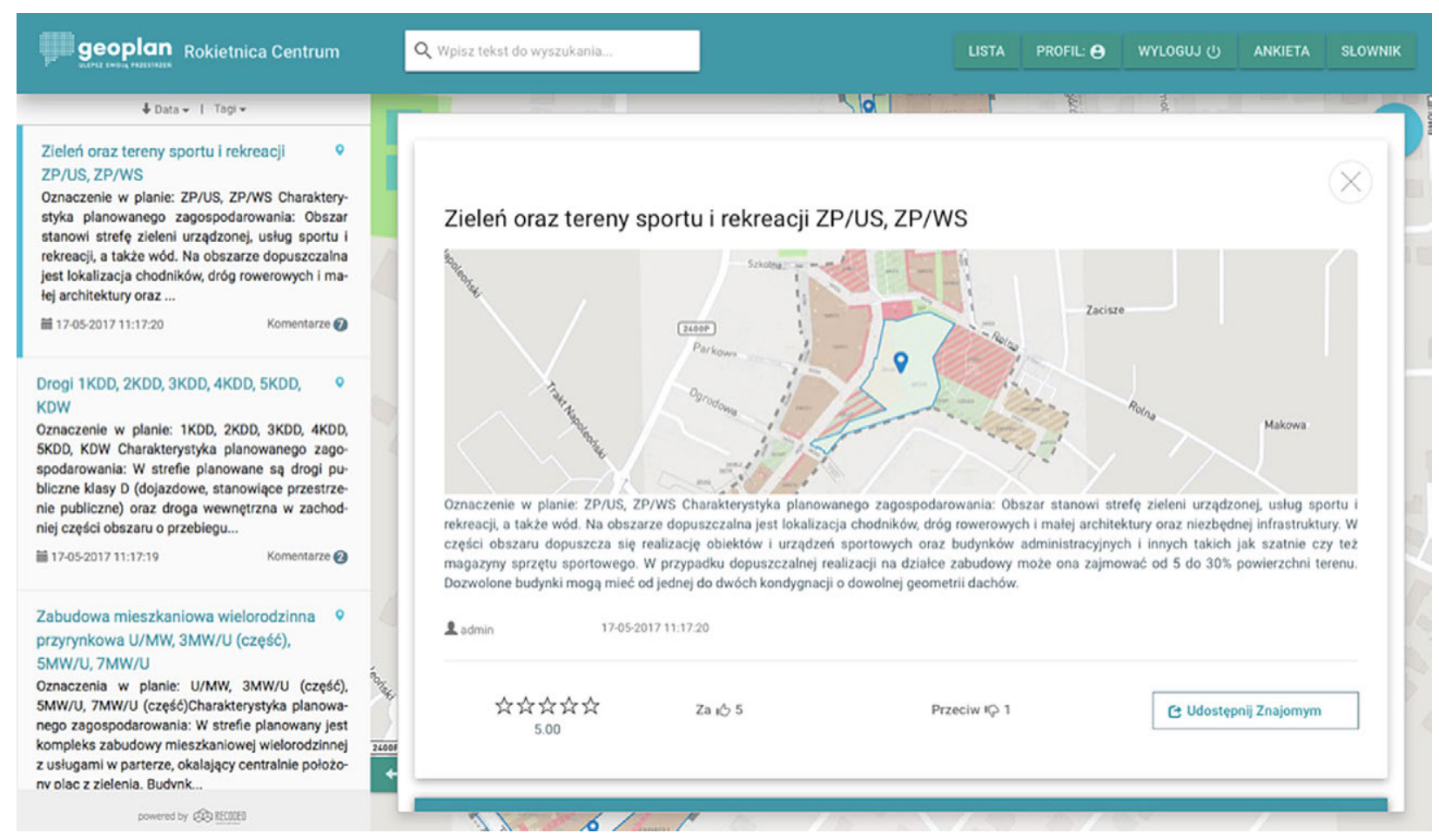

Fig. 6. Example of geo-discussion used in the public consultations in Rokietnica. The page shows an interactive description of one of the sections of the plan.

One of the most important characteristic of qeo-discussion is that the users (participants) not only see the inputs of their peers, but also are encouraged to interact with each other. Therefore, individual position statements/postulates/answers are not independent from each other and the communication is generally multidirectional. This, on the one hand, constitutes an opportunity for different parties to exchange their opinions and negotiate possible solutions. Also, the plan designer can use the features of geo-discussion to deepen the understanding of users' preferences.

On the other hand, the bi-directional character of geo-discussion can complicate the analysis of collected data, since the final discussion content might be influenced by early participant inputs and comments generally lack the structure typical to answers in a questionnaire. Consequently, geo-discussion inputs should be treated qualitatively, since the data can not be easily aggregated. Another issue affecting the content obtained during geo-discussion is the effective involvement of discussion moderator, whose role is not only managing the discussion and explaining technical content but also mediation in case of conflicts between stakeholders. In contrast to geo-questionnaire, the common characteristic of the uses of geo-discussion is the focus on interaction and bidirectional exchange of information. The relatively free form of opinion exchange induces mutual communication that can support collaborative decision-making, albeit conditioned by a number of other factors. As noted by Sieber (2006), broader discussion and communication as well as consensus building are the expected results of PPGIS. The important aspect of the discussion on spatial development plans (and other ideas connected with space) enabled by geo-discussion is the awareness of online agora specifics (Bishop 2006). The engagement of participants, especially representing groups of interests, can be easily increased with the use of social media. That said, digital divide is still an important barrier that should be considered in the development of cyber democracy (Hacker, van Dijk 2000). Therefore, to get useful results from the use of online methods such as geo-discussion, it is necessary to properly plan public consultations by carefully considering convening factors and constraints, process flow, and expected outcomes (Kain, Söderberg 2008, Cuppen 2012).

The abovementioned characteristics confine the use of geo-discussion to situations, in which 


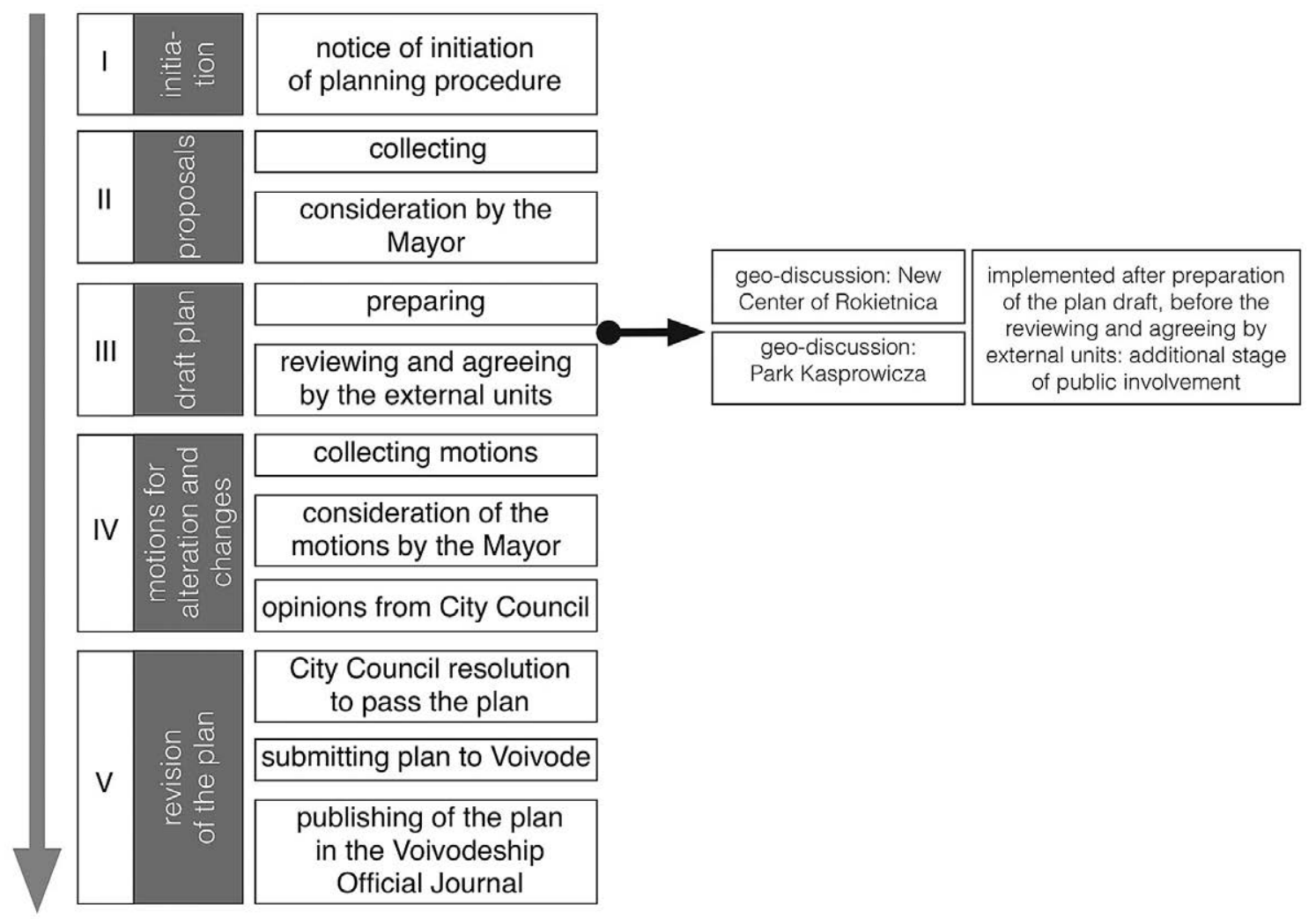

Fig. 7. Implementation of geo-discussion within the planning procedure of the analyzed local land use plans.

the organisers either wish to collect feedback on the working version of document (e.g. a local plan) or try to foster the process of building a consensus around the plan. Since both situations require a draft proposal of the plan, geo-discussion lends itself to be used primarily in later phases of statutory planning procedure in Poland (see: phase III in Fig. 7).

In the discussed case studies, geo-discussion was used at the stage of elaborating the first draft of plan, just before it undergoes mandatory reviewing and agreeing with external bodies. The aim of both uses was to present the draft plan to the public and to collect feedback on it. As the statutory procedure does not require to collect any input from citizens at this stage, the input could be used informally to alter the content of plans and would not require an official response from the authority (required in case of statutory motions and comments).

\section{Recommendations for the use of geo- questionnaire and geo-discussion}

Based on the interviews conducted to identify the needs of potential geo-questionnaire and geo-discussion users, the following benefits of their use in spatial planning were identified:

- the inclusion of larger group of people in a consultation process,

- increased participation of youth in consultations,

- more precise definition of needs, especially in the spatial context (map based),

- facilitating broader access to participation in planning by removing the requirement of attending a public meeting at a specific place and a specific time,

- facilitating a stress-free expression of opinion/position on an issue for people who are uncomfortable speaking out at public fora,

- allowing for quantitative analysis of social preferences related to spatial organization (geo-questionnaire only),

- increasing the transparency of the decision-making process, thus increasing their social acceptance,

- facilitating visualization of local spatial development plan draft,

- faster interaction with residents,

- lower costs of opening participation to larger groups, 
- possibility of participants getting disappointed in light of their preferences not included in the plan, and in consequence becoming disillusioned with participating in the future,

- the anonymity of expression (that can influence 'hate-speech' on the Web).

In addition, the interviewees pointed out that the residents' proposals and questions could be answered after the consultation by the representatives of other units of the city, which is not possible during traditional meetings unless those representatives are present at the meetings. Aside from the advantages, the potential constraints and threats to the use of Geoweb methods mentioned by the interview respondents included an overrepresentation of younger people participating in public consultations who are comfortable with mobile and Internet tools or technical issues related to the obsolescence of participants' communication tools. The respondents mentioned also potential additional costs caused by the use and configuration of application or the greater engagement of planning professionals working outside the office hours. Other potential threats arise from incomplete participant knowledge causing varying levels of details in discussion contributions and the difficulty keeping the discussion focused on the topic of consultation.

According to all interviewees, the Geoweb methods, in order to measure up to expectations and to be fully useful for planners, should be characterized by intuition and simplicity of their use.

\section{Summary}

The deployment of geo-questionnaire and geo-discussion in support of public participation in planning processes depends on the problem at hand and the phase of planning procedure. In sum, geo-questionnaire can be useful at the initial phase of the local spatial development plan preparation, specifically in establishing: (1) if the planned changes/interventions are necessary and what is public opinion in regard to potential investment plans in the area, or (2) during the phase, in which plan guidelines are formulated. Geo-questionnaire, in light of the analyzed cases, can be used for consulting the objectives of plan at the second stage of public consultations mandated by legal acts.
While there are organizational possibilities for the implementation of Geoweb tools in spatial planning, the interviewees also recognized potential barriers to their use due to legal barriers. As some authors indicate, there are also technological constraints that may constitute a lesser obstacle than legal constraints (Cliquet et al. 2010, Ganapati 2010). As already pointed out in the paper, there is a strong need for giving legal status to the results of consultations conducted with the use of Geoweb methods. The need has not only legal bases, but is also motivated by the necessity to change the opinion on e-participation as an „electronic suggestion boxes" (Kersting et al. 2016).

Despite the fact that there have been positive opinions of urban planners and local authorities on the use of geo-questionnaire and geo-discussion in spatial planning, the potential barrier to using Geoweb methods may be the apprehension of decision makers not only towards overloading the decision-making process with information but also to opening public consultations to new forms. This would provide a strong argument for the reinforcement of public expectations for planning decisions that are not always the same from the point of view of local authorities focused on economic benefits or cost of spatial planning. These aspects of introducing Geoweb methods to public consultations are related to opening local governments to more inclusive model of decision-making, in which new media and e-consultations can be a way to improve the quality of services and public trust (Denters 2017).

\section{Acknowledgements}

Research described in this article was conducted as part of the project Geoportal supporting public participation in spatial planning financed by the National Research and Development Center (contract number PBS3/A9/39/2015). The authors gratefully acknowledge the support of the Poznan City Hall, Łódź City Hall, Rokietnica Municipal Office and Swarzędz Municipal City Hall.

\section{References}

Act of 27 March 2003 on spatial planning and management (Journal of Laws 2003 no. 80 item 717) (Ustawa $z$ dnia 27 marca 2003 roku o planowaniu i zagospodarowaniu przestrzennym, Dz.U. $2003 \mathrm{Nr} 80$ poz. 717). 
Anttiroiko A.-V., 2012. Urban Planning 2.0. International Journal of E-Planning Research 1(1): 16-30. DOI:10.4018/ ijepr.2012010103.

Banyan M.E., 2007. Participation. In: Bevir M. (ed.), 2007. Encyclopedia of Governance. Sage Publications: 659-633.

Bishop J., 2007. Increasing participation in online communities: A framework for human-computer interaction. Computers in Human Behavior 23, 1881-1893.

Brabham, D. C. 2009. "Crowdsourcing the Public Participation Process for Planning Projects." Planning Theory 8 (3): 242-262. doi:10.1177/1473095209104824.

Broberg, A., Kyttä, M., \& Fagerholm, N. (2013). Child-friendly urban structures: Bullerby revisited. Journal of Environmental Psychology, 35, 110-120.

Brown G., Kytta M., 2014. Key issues and research priorities for public participation GIS (PPGIS): A synthesis based on empirical research. Applied Geography 46: 122-136.

Cliquet A., Kervarec F., Bogaert D., Maesa F., Queffelec B., 2010. Legitimacy issues in public participation in coastal decision making processes: Case studies from Belgium and France. Ocean \& Coastal Management, 53: 760-768.

Cuppen E., 2012. Diversity and constructive conflict in stakeholder dialogue: considerations for design and methods. Policy Sciences 45(1): 23-46.

Dear M., 1992. Understanding and Overcoming the NIMBY Syndrome. Journal of the American Planning Association 58(3): 288-300.

Denters B., 2017. Participation and Democratic Accountability: Making a Difference for the Citizens. In: Schwab Ch., Bouckaert G., Kuhlmann S. (eds.), The Future of Local Government in Europe Lessons from Research and Practice in 31 Countries: 79-100.

Eurostat, 2017. Being young in Europe today - digital world. Online: ec.europa.eu/eurostat/statistics-explained/ index.php/Being_young_in_Europe_today_-_digital_ world (accessed 26 June 2018).

Ganapati S., 2010. Using geographic information systems to increase citizen engagement. IBM Center for the Business of Government. Online: www.businessofgovernment. org/sites/default/files/GanapatiReport.pdf (accessed 16 November 2017).

Gryl I., Jekel T., Donert K., 2010. Geoinformation and Spatial Citizenship. Learning with GeoInformation, V, 2-11.

Hacker K.L., van Dijk J., 2000. What is digital democracy? In: K.L. Hacker, J. van Dijk (eds.), Digital Democracy: Issues of Theory and Practice, SAGE Publications, London: 1-9.

Haklay M., Singleton A., Parker Ch., 2008. Web Mapping 2.0: The Neogeography of the GeoWeb. Geography Compass 2(6): 2011-2039.

Henning S., Vogler R., Gryl I., 2013. Spatial Education for Different User Groups as a Prerequisite for Creating a Spatially Enabled Society and Leveraging SDI. International Journal of Spatial Data Infrastructures Research 8: 98-127.

Herbst K., 2014. Partycypacja a prawo do miasta. In: Partycypacja społeczna w planowaniu przestrzennym, Konferencja Towarzystwa Urbanistów Polskich Oddziału w Warszawie oraz Biura Architektury i Planowania Przestrzennego Urzędu m.st. Warszawy: 7-15.

Jankowski P., Czepkiewicz M., Młodkowski M., Zwoliński Z., 2016. Geo-questionnaire: A Method and Tool for Public Preference Elicitation in Land Use Planning. Transactions in GIS 20(6): 903-924.

Jankowski P., Czepkiewicz M., Młodkowski M., Zwoliński Z., Wójcicki M., 2017. Evaluating the scalability of public participation in urban land use planning: A comparison of Geoweb methods with face-to-face meetings. Environment and Planning B: Urban Analytics and City Science: 1-23, DOI: $10.1177 / 2399808317719709$

Jankowski P., Kaczmarek T., Zwoliński Zb., Bąkowska-Waldmann E., Brudka C., Czepkiewicz M., Mikuła Ł., Młodkowski M., 2018. Zastosowanie aplikacji geoankiety i geodyskusji w partycypacyjnym planowaniu przestrzennym - dobre praktyki. Biblioteka Aglomeracji Poznańskiej 32: 7-81.

Johnson P. A., Corbett J. M., Gore C., Robinson P., Allen P., Sieber R., 2015. A Web of Expectations: Evolving Relationships in Community Participatory Geoweb Projects. ACME: An International Journal for Critical Geographies 14(3): 827-848.

Kahila-Tani M., Broberg A., Kyttä M., Tyger T., 2015. Let the Citizens Map - Public Participation GIS as a Planning Support System in the Helsinki Master Plan Process. Planning Practice \& Research 31(2): 195-214.

Kain J.H., Söderberg H., 2008. Management of complex knowledge in planning for sustainable development: the use of multi-criteria decision aids. Environmental Impact Assessment Review 28(1): 7-21.

Kersting N., Gasparikova J., Iglesias A., Krenjova J., 2016. Local Democratic Renewal by Deliberative Participatory Instruments: Participatory Budgeting in Comparative Study. In: Kuhlmann S., Bouckaert G. (eds.): Local Public Sector Reforms in Times of Crisis: National Trajectories and International Comparisons. London: Palgrave Macmillan: 317-331.

Kraft M.E., Clary B.B., 1991. Citizen Participation and the Nimby Syndrome: Public Response to Radioactive Waste Disposal. The Western Political Quarterly 44(2): 299-328.

Matczak P., 1996. Społeczne uwarunkowania eliminacji syndromu NIMBY. In: R. Cichocki (ed.), Podmiotowość społeczności lokalnej. Poznań.

Niewiadomski Z., 2002. Planowanie przestrzenne. Zarys systemu. Wydawnictwo Prawnicze, LexisNexis, Warszawa.

Nordin K., Berglund U., 2010. Children's maps in GIS: A tool for communicating outdoor experiences in urban planning. International Journal of Information Communication Technologies and Human Development 2(2): 1-16. DOI: $10.4018 /$ jicthd.2010040101.

Parysek J.J., 2007. Wprowadzenie do gospodarki przestrzennej. Wybrane aspekty praktyczne. Wydawnictwo Naukowe UAM, Poznań.

Raport o ekonomicznych stratach i społecznych kosztach niekontrolowanej urbanizacji w Polsce, 2013. Fundacja Rozwoju Demokracji Lokalnej i Instytut Geografii i Przestrzennego Zagospodarowania PAN. Online: http://www.frdl.org.pl/pliki/frdl/document/ zalaczniki_artykuly/Raport\%20Ekonomiczny \% 20 29.10.2013\%20calosc.pdf (accessed: 15 November 2017)

Radeberg-Skorzysko M., 2016. Sporządzanie planu miejscowego zgodnie z przepisami odrębnymi odnoszącymi się do jego obszaru. In: M. Wiland, E. Hubicka, A. Derc, A. Woźniak (eds.). Problemy planistyczne - jesień 2016, 2/2016. Stowarzyszenie Urbanistów ZOIU: 57-84.

Regulation of the Minister of Infrastructure of 26 August 2003 on the required scope of the local spatial development plan (Rozporzadzenie Ministra Infrastruktury z dnia 26 sierpnia 2003 roku w sprawie wymaganego zakresu projektu miejscowego planu zagospodarowania przestrzennego).

Robson C., 1993. Real World Research: A Resource for Social Scientists and Practitioners-Researchers. Blackwell, Oxford. 
Sieber R., 2006. Public participation geographic information systems: A literature review and framework, Annals of the Association of American Geographers 96(3): 491-507.

Siemiński W., 2014. Partycypacja spontaniczna a kształtowanie przestrzeni. In: Partycypacja społeczna w planowaniu przestrzennym, Konferencja Towarzystwa Urbanistów Polskich Oddziału w Warszawie oraz Biura Architektury i Planowania Przestrzennego Urzędu m.st. Warszawy: 33-55.
Talen E., 2000. Bottom-Up GIS. Journal of the American Planning Association 66(3): 279-294.

Yin R.K., 2003. Case studies research: design and methods. Thousand Oaks: Sage.

Zachariasz I., 2014. Partycypacja w procesie planowania przestrzennego jako prawo podmiotowe. In: Partycypacja społeczna w planowaniu przestrzennym, Konferencja Towarzystwa Urbanistów Polskich Oddziału w Warszawie oraz Biura Architektury i Planowania Przestrzennego Urzędu m.st. Warszawy: 16-32. 